\title{
Rainbands, Precipitation Cores and Generating Cells in a Cyclonic Storm ${ }^{1}$
}

\author{
Peter V. Hobes and John D. Locatelli \\ Atmospheric Sciences Department, University of Washington, Seatle 98195 \\ (Manuscript received 27 June 1977, in final form 7 October 1977)
}

\begin{abstract}
The mesoscale organization and structure of precipitation in a cyclonic storm have been studied using satellite, radar, airborne and ground measurements. The large mesoscale regions, which were mainly in the form of rainbands, contained within them smaller mesoscale regions (precipitation cores) which were characterized by higher rainfall rates. It is shown that the precipitation cores in warm frontal bands originated in generating cells aloft which provided "seed" ice crystals which grew by collection as they fell through lower cloud layers. The generating cells were probably produced by the lifting of shallow layers of potentially unstable air which were situated above warm fronts. There is also some evidence that the precipitation cores within cold frontal bands originated within layers of potentially unstable air.
\end{abstract}

\section{Introduction}

Early radar studies of precipitation in mid-latitudes revealed that the characteristic "mares' tails" or streamers of snow, which are often seen in radar displays, are due to the continuous formation of snow crystals in generating cells aloft (Bowen, 1951; Browne, 1952; Marshall, 1953). Plank et al. (1955) suggested that the streamers from generating cells might play an important role in the development of stratiform precipitation, and Boucher (1959) showed that various types of streamers were associated with different synoptic situations. Wexler and Atlas (1959) pointed out that generating cells are probably formed by the lifting of convectively unstable layers of air.

In more recent years observational studies (still primarily radar) of extratropical cylonic storms have tended to emphasize the mesoscale organization of the precipitation. Thus, it is now established that large mesoscale areas $\left(\sim 10^{3}-10^{4} \mathrm{~km}^{2}\right)$ of precipitation associated with cyclonic storms are often band-shaped (e.g., Browning et al., 1973; Houze et al., 1976), and that small mesoscale areas $\left(\sim 10-10^{2} \mathrm{~km}^{2}\right)$ of relatively high intensity precipitation exist within the large mesoscale areas (Austin and Houze, 1972.)

During the past few years the Cloud Physics Group at the University of Washington has been engaged in a study of cyclonic extratropical storms (the CYCLES PROJECT) in the Pacific Northwest on scales ranging from the synoptic, through the mesoscale, and down to the microphysical scale. In this paper we describe some detailed radar, airborne and ground observations of small mesoscale regions of precipitation (which we call precipitation cores, or cores for short) within

${ }^{1}$ Contribution No. 444, Atmospheric Sciences Department, University of Washington. rainbands and show how they are related to generating cells.

\section{Observational facilities}

In order to obtain detailed information on the structure of cyclonic storms over a wide variety of scales, the CYCLES PROJECT employs simultaneous observations and measurements from satellites, aircraft, radar and ground stations. Fig. 1 shows a schematic diagram of the facilities which were used in the studies to be described in this paper.

Satellite (SMS-2) cloud photographs, available every half-hour at the University of Washington (UW), and National Weather Service (NWS) synoptic data provided an overview of the storms we studied. The NWS low-resolution weighing bucket raingages (some of which can resolve rainfall amounts of $\sim 0.5 \mathrm{~mm}$ over periods of $7 \mathrm{~min}$ ) were supplemented by a number of UW high-resolution tipping bucket gages which could detect $\sim 0.04 \mathrm{~mm}$ of rain per tip (about every $15 \mathrm{~s}$ in moderate rain). Rainfall rates from the UW gages were relayed continuously and automatically to the UW. Rawinsondes were launched from the UW in Seattle every $1 \frac{1}{2}$ to $3 \mathrm{~h}$. These serial soundings were used to construct time-height sections of temperature, humidity, winds and wet-bulb potential temperature through the frontal systems passing over the area.

The UW operated two radars in Seattle. One was a weather surveillance radar (wavelength $3.2 \mathrm{~cm}$, beamwidth $1.5^{\circ}$, and peak power $250 \mathrm{~kW}$ ) which operated in an approximately horizontal PPI scanning mode and detected precipitation at five different reflectivity intensity levels within a radius of $80 \mathrm{~km}$ from Seattle. This radar was particularly useful since it completed a PPI scan every $45 \mathrm{~s}$, permitting the tracking of 


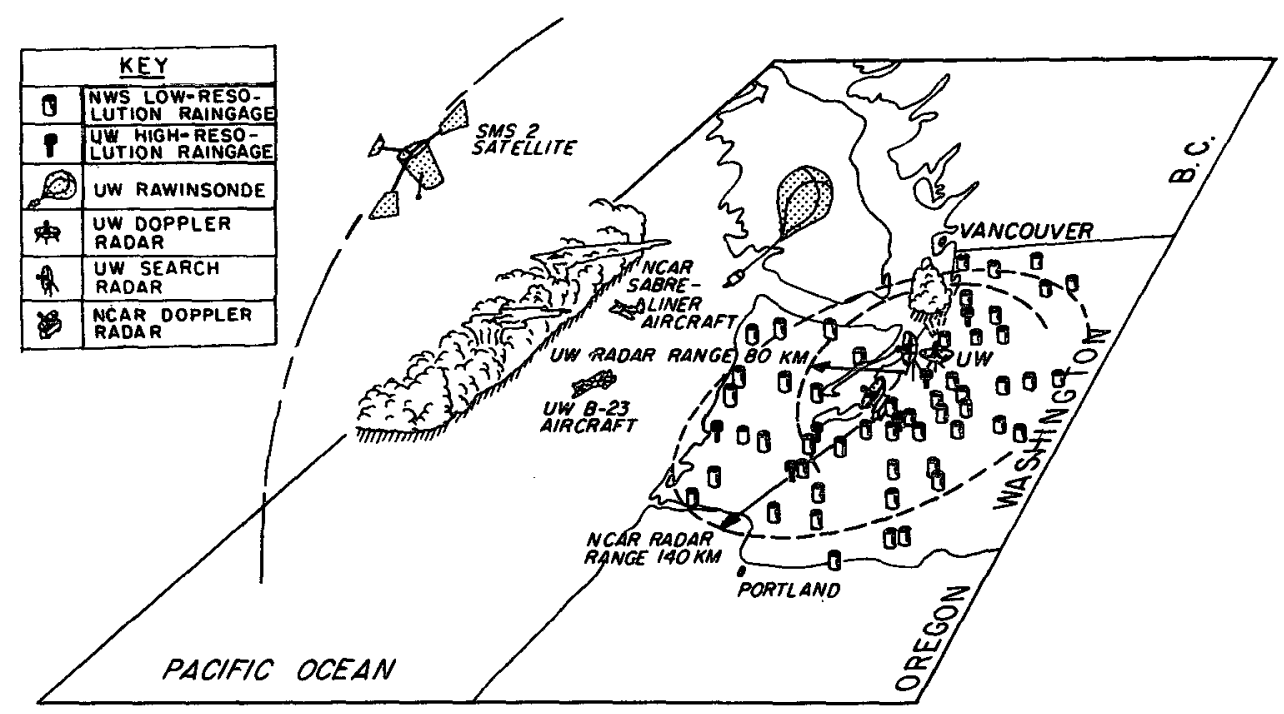

FIG. 1. Schematic of the observational facilities for the CYCLES PROJECT. UW indicates location of the University of Washington.

precipitation cores. The other UW radar was a vertically pointing pulsed Doppler radar (wavelength $3.2 \mathrm{~cm}$, beamwidth $0.8^{\circ}$, peak power $7 \mathrm{~kW}$ ) which measured the spectrum of Doppler velocities of precipitation at ten different heights above the radar every $50 \mathrm{~s}$. A third radar, operated by the National Center for Atmospheric Research (NCAR), was located in Tacoma. This was NCAR's CP-3 color display (Gray et al., 1975) Doppler radar (wavelength $5.45 \mathrm{~cm}$,

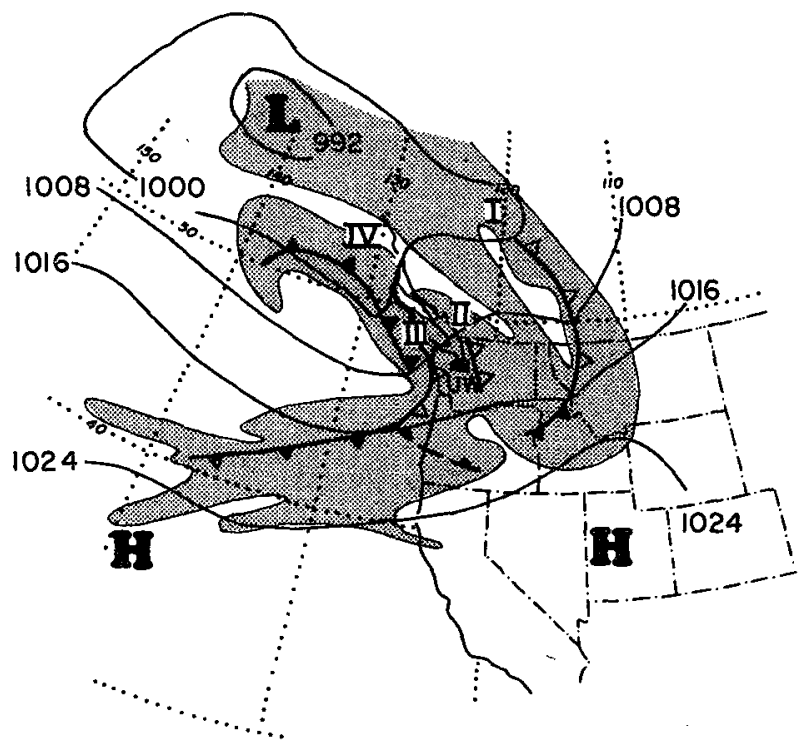

FIg. 2. Synoptic maps for 1600 PST 10 January 1976. Isobars are labeled in $\mathrm{mb}$. Surface and upper level fronts are indicated in the conventional way and weak fronts are indicated by dashed lines. The location of the University of Washington (UW) is indicated by the black dot. The upper cloud shields (derived from SMS-2 satellite photographs) are shown by the stippled areas. beamwidth $1^{\circ}$, peak power $338 \mathrm{~kW}$ ) which provided PPI and RHI scans of reflectivity and Doppler velocities of the precipitation particles.

Aircraft coverage was provided by the UW's B-23 research aircraft and NCAR's Sabreliner. Measurements aboard the B-23, which were transmitted to the ground in Seattle, included air temperature, dew-point temperature, cloud liquid water content, turbulence, cloud and precipitation particle size spectra, and the types of cloud and precipitation particles. For more complete information on this facility the reader is referred to Hobbs et al. (1975). The Sabreliner provided measurements of air temperature, air motions and the size spectra of precipitation particles. The aircraft flights were coordinated from a control center at the UW where the UW radar, raingage and satellite data were displayed in real-time. An observer at the CP-3 radar was in constant communication with the control center. When large mesoscale areas of precipitation were identified, the aircraft were directed into them at different levels and they remained within these mesoscale areas as they moved across the observational network.

\section{Overview of synoptic situation in which measurements were obtained}

The synoptic situation during the period of observations with which we are concerned in this study is shown in Fig. 2. Four fronts (labeled I-IV in Fig. 2) passed over the UW. The existence of these fronts was deduced primarily from detailed time-lapse sequences of the cloud and precipitation patterns shown by satellite and radar. A detailed synoptic study of these fronts will be described in another paper. 


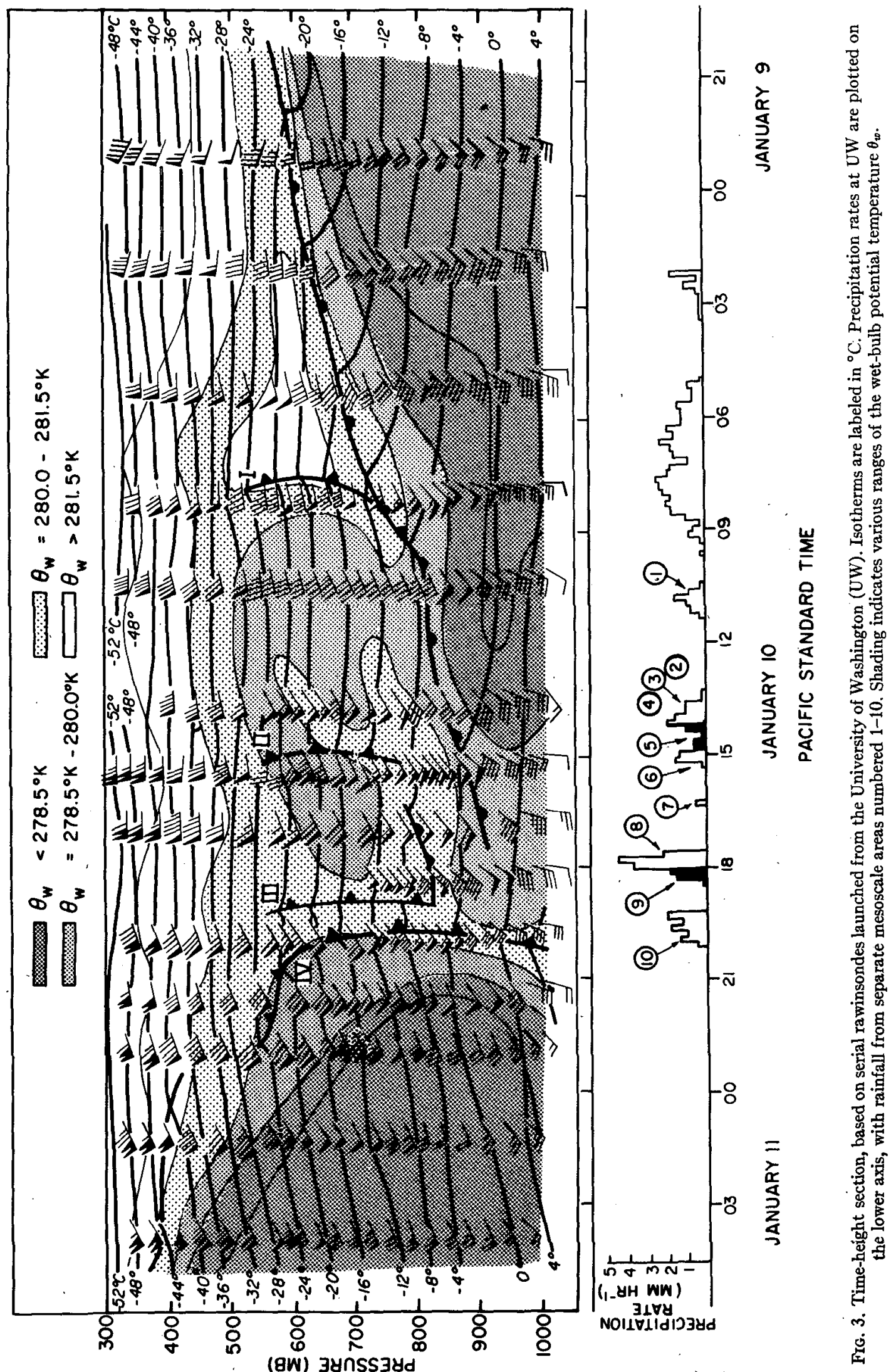




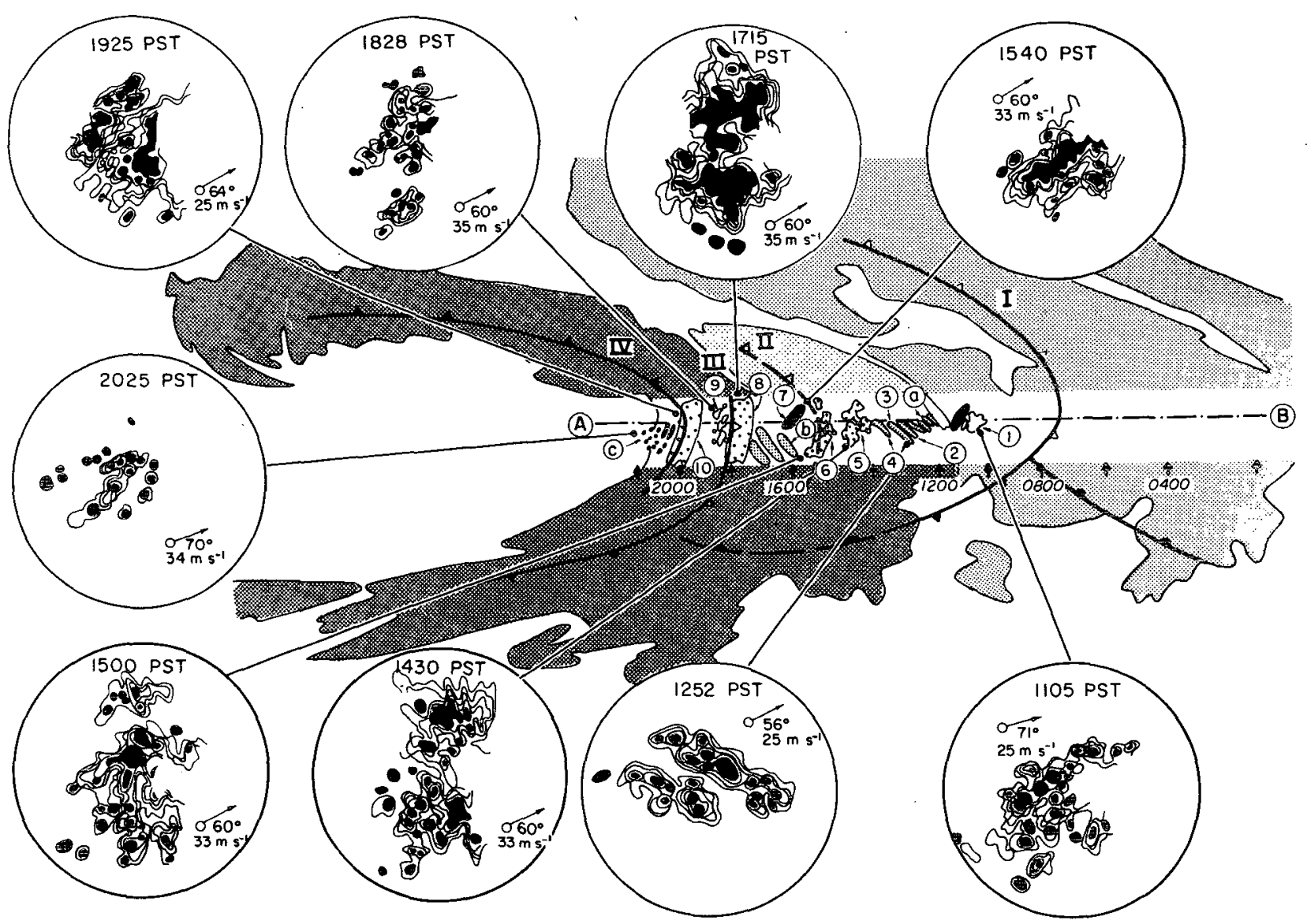

FIG. 4. Horizontal section through the four fronts (labeled I-IV) on 10 January. Line AB is the path of the cyclonic storm over the UW. The times along AB as indicated by the black arrows are Pacific Standard Times. The expanded views of the rainbands are contained within circles of $80 \mathrm{~km}$ radius. The black areas are precipitation cores. The arrows within each circle show the speed and direction of the motion of the cores. The three different stippled areas indicate the upper cloud shields (as revealed by satellite photographs) associated with fronts I, II and III and IV, respectively.

Early in the morning on 10 January, front I moved across western Washington and by 1600 PST was over Montana and Idaho. Front II at this time was directly over western Washington. Front III was associated with a wave which developed on a major frontal system southwest of Washington. The fourth front (IV) was associated with a comma-shaped cloud pattern which formed in the polar air west of front III and rapidly approached the developing wave.

A time-height section in Fig. 3 presents rawinsonde data collected at the UW and suggests a possible vertical structure for the four frontal features. It can be seen that several regions of potential instability, where the wet-bulb potential temperature decreased with height, passed over the UW.

\section{Large mesoscale precipitation areas within the storms}

Fig. 4 shows a horizontal section of the storm as it appeared over the UW. (The time-height section in Fig. 3 matches in time the line $A B$ in Fig. 4.) The mesoscale rainfall areas associated with fronts 1-IV were determined by combining the PPI data from the UW and NCAR radars; these are also shown in Fig. 4. The numbered rainfall areas in Fig. 4 correspond to their numbered rainfall traces in Fig. 3. The mesoscale rainfall areas labeled with letters in Fig. 4 did not pass over the UW. The unshaded strip in Fig. 4 is the section through the frontal systems covered by the combined radar data. The rainfall areas were divided into warm frontal rainbands oriented north-south, post-frontal rainbands oriented northeast-southwest, and mesoscale areas of no discernable orientation or bandlike shape. These mesoscale rainband orientations confirm the frontal analysis in Fig. 2.

Our classification of the large mesoscale precipitation within the two storms is shown in Table 1. The numbers and letters in the body of Table 1 correspond to the mesoscale areas and the rainfall traces noted in Figs. 3 and 4. 
Table 1. Classification of the large mesoscale precipitation areas. The numbers and letters in the body of the table correspond to the mesoscale areas and the rainfall traces noted in Figs. 3 and 5 . The type of rainband noted in parentheses is based on the classification suggested by Houze et al. (1976)*.

\begin{tabular}{|c|c|c|c|c|}
\hline $\begin{array}{l}\text { Frontal } \\
\text { number }\end{array}$ & $\begin{array}{l}\text { Bands with } \\
\text { warm frontal } \\
\text { orientation }\end{array}$ & $\begin{array}{l}\text { Cold frontal } \\
\text { rainbands }\end{array}$ & $\begin{array}{l}\text { Post frontal } \\
\text { rainbands }\end{array}$ & $\begin{array}{c}\text { Irregular } \\
\text { mesoscale } \\
\text { areas }\end{array}$ \\
\hline$I$ & $\begin{array}{l}\text { no data } \\
\text { available }\end{array}$ & $\begin{array}{l}\text { no data } \\
\text { available }\end{array}$ & 1 & 1 \\
\hline II & $\begin{array}{l}\text { a, } 2,3,4 \\
\text { (Type 5) }\end{array}$ & $\begin{array}{l}5,6 \\
\text { (Type 3) }\end{array}$ & 7 & - \\
\hline III & $\begin{array}{c}\text { b } \\
\text { (Type 5) }\end{array}$ & $\begin{array}{l}8,10 \\
\text { (Type 3) }\end{array}$ & $\begin{array}{c}c \\
\text { (Type 6) }\end{array}$ & 9 \\
\hline IV & - & $\begin{array}{l}10 \\
\text { (Type 3) }\end{array}$ & $\begin{array}{c}\text { c } \\
\text { (Type 6) }\end{array}$ & - \\
\hline
\end{tabular}

* Type 3 : Cold frontal: Wide rainbands approximately $50 \mathrm{~km}$ in width oriented parallel to the cold front and found toward the trailing edge of a frontal cloud shield.

Type 5: Wavelike: Occurring in a very regular pattern similar to waves.

Type 6: Post frontal: Rainbands located in the convective clouds behind the frontal cloud shield.

The group of four rainbands collectively indicated by (a) in Fig. 4 (which we will refer to as rainbands $a_{1}$, $a_{2}, a_{3}$ and $a_{4}$ ), together with bands 2, 3 and 4 in Fig. 4, formed a wavelike train. All of these rainbands were located in the warm frontal portion ahead of the second upper level cold front. The characteristics of these rainbands are listed in Table 2. Their longitudinal axes were oriented roughly perpendicular to the direction of the mean wind below $550 \mathrm{mb}$, their average width was $17 \mathrm{~km}$, and their average speed $22 \mathrm{~m} \mathrm{~s}^{-1}$. Considered as a wave, the average wavelength was 23 $\mathrm{km}$ and the average period $17 \mathrm{~min}$.

\section{Internal structure of the rainbands : Precipitation cores}

\section{a. Radar PPI observations}

Shown in Fig. 4 are the precipitation cores (detected by the UW surveillance radar) within each of the large mesoscale precipitation areas previously discussed. The cores were generally tens of square kilometers in area, but in a few cases they merged to form precipitation areas on the order of hundreds of square kilometers.

Examples of how the precipitation cores evolved in time for two rainbands (3 and 4) are given in Fig. 5, and the paths of these cores are shown in Fig. 6. It is clear from Fig. 5 that the cores occupied an appreciable fraction of the total area of each rainband, and therefore probably contributed an important component to the total precipitation in the rainband. Comparison of Fig. 5 and 6 reveals that cores located in the southeastern portions of rainbands 3 and 4 moved more toward the north than the other cores; this may have been due to a channeling effect of the Olympic and Cascade Mountains. A more detailed account of the characteristics of the cores in rainbands 3 and 4 is given in Table 3 . The average core area was $28 \mathrm{~km}^{2}$; however, if the three unusually large cores are excluded the average area was $23 \mathrm{~km}^{2}$. The lifetimes of the cores varied from 2 min to over $30 \mathrm{~min}$. Motions were computed for only those cores which could be tracked for at least $10 \mathrm{~min}$. The average speed and direction of motion for the cores located in the southeastern portions of the rainbands, which tended to move to the north, were $18 \mathrm{~m} \mathrm{~s}^{-1}$ and $15^{\circ}$ (from true north), while for the remaining cores the corresponding values were $25 \mathrm{~m} \mathrm{~s}^{-1}$ and $56^{\circ}$. The motions of the cores did not appear to depend on the type or the orientation of the rainband in which they were located. The relationship

TABLE 2. Some characteristics of the wavelike rainbands in the warm frontal portion of front $I$.

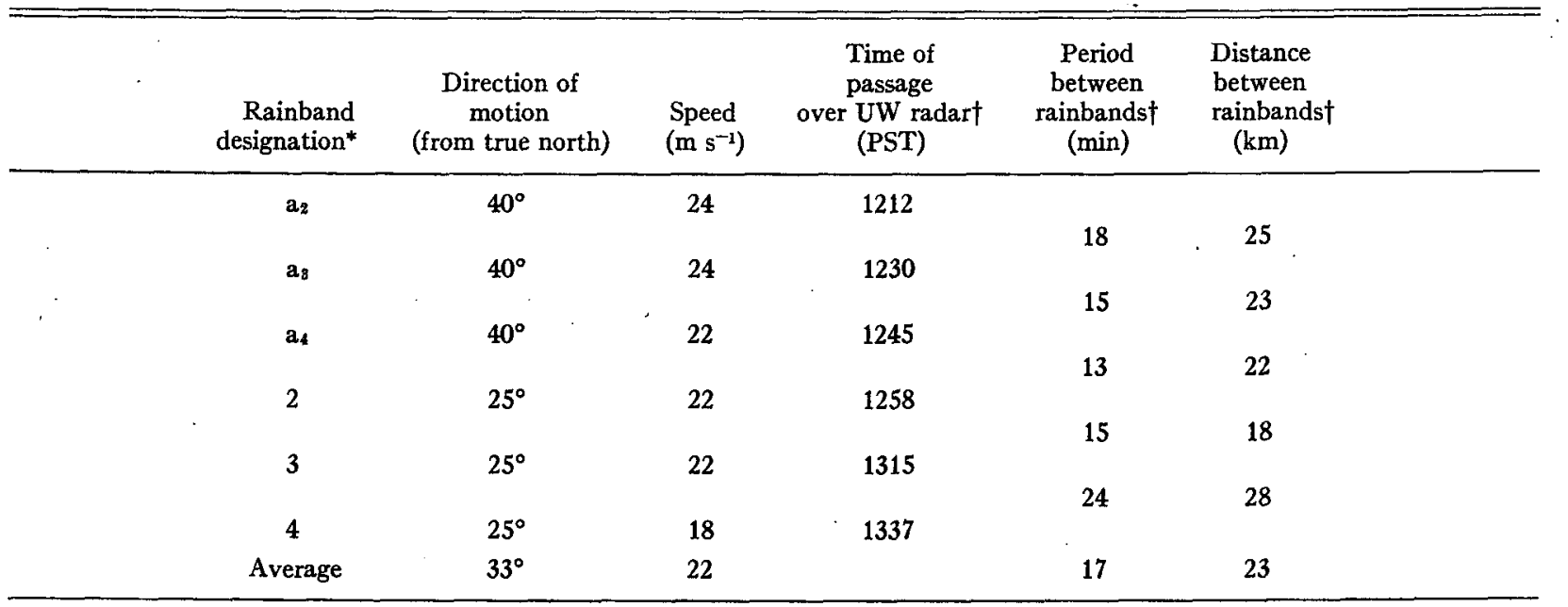

* Rainband $a_{1}$ was not trackable.

$\dagger$ Measured at center of rainbands. 


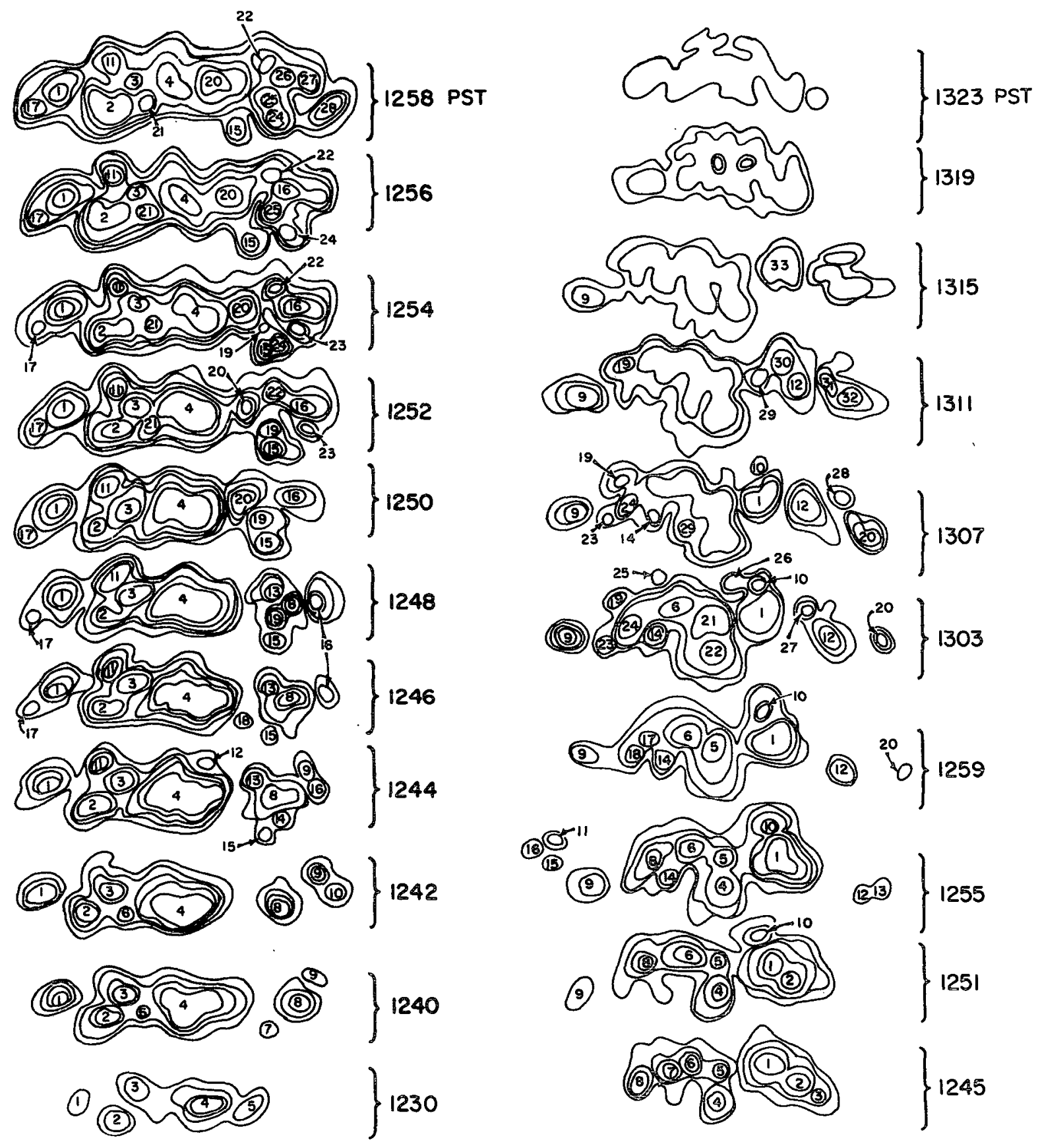

(a)

(b)

FIG. 5. (a) Reflectivity contours for rainband No. 3 in Fig. 4. Time of observation is given to the right of each band. Cores of heavier precipitation are numbered and can be traced in time. (b) As for (a) but for rainband 4 in Fig. 4.

of the motion of the cores to the larger scale wind field will be discussed later in this paper.

The cores in rainband 4 became increasingly difficult to discern as they approached the radar (increasing time in Fig. 5b) and by 1323 PST no cores were discern- ible. However, this was not the case for the cores in rainband 3 (see Fig. 5a), even though it was tracked just as close to the radar as rainband 4 . The precipitation rates in rainband 4 were about $1 \mathrm{~mm} \mathrm{~h}^{-1}$, whereas those in rainband 3 were less than $0.5 \mathrm{~mm} \mathrm{~h}^{-1}$. The 


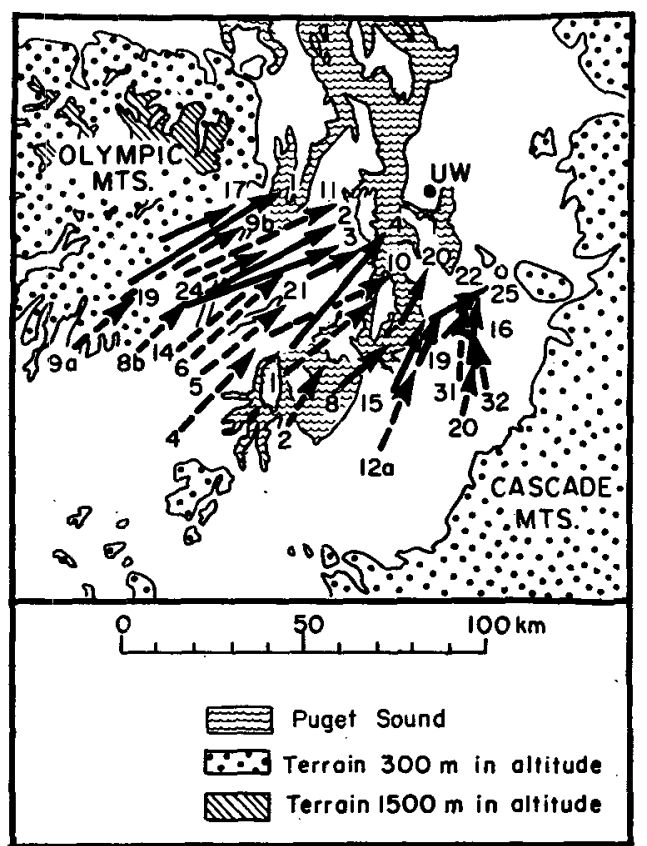

FIG. 6. Paths of the precipitation cores in rainband 3 (solid arrows) and rainband 4 (dashed arrows). The numbers correspond to the core numbers shown in Fig. 5.

difficulty in discerning the cores in rainband 4 was probably due to attenuation and the lack of sufficient resolution in the intensity levels on the radar.

\section{b. Airborne, Doppler radar and raingage measurements}

Information on the cores in the cold-frontal rainband 8 was also provided by airborne, vertically pointing Doppler radar and raingage measurements. Fig. 7 shows measurements in rainband 8 obtained from the aircraft, the UW Doppler radar and the UW highresolution raingage. The aircraft data were obtained about $40 \mathrm{~min}$ before the rainband passed over the UW and the aircraft flew through the shafts of precipitation close to the base of a potentially unstable layer of air (see Fig. 8). The spatial scale of the cores, as determined from PPI radar observations, was about $4-6 \mathrm{~km}$; this scale is indicated in each part of Fig. 7.

The following facts emerge from the data shown in Fig. 7:

- Core-size fluctuations can be discerned in the measurements of cloud liquid water contents, particle spectra, fallspeeds of the precipitation particles and in the precipitation rates measured on the ground.

- The triangular shapes of the concentration isopleths in section $\mathrm{C}$ of Fig. 7 indicate that the largest particles in precipitation cores are located at their centers and the concentrations of particles of any given size increase toward the center of a precipitation core. This is probably due to aggregates growing faster at the centers of cores where the crystal concentrations are highest.
- Particles as large as $3.5 \mathrm{~mm}$ were present within the precipitation cores at the flight level of the aircraft, and the concentrations of $2 \mathrm{~mm}$ particles at this level were as high as $0.5 l^{-1}$.

- It is apparent from the high-resolution raingage and aircraft data that each core contained smaller areas of precipitation within it. These smaller areas are on the order of $1-3 \mathrm{~km}^{2}$.

An interesting contrast can be seen between rainband 8 (marked by its front and back edges in section $\mathrm{C}$ of Fig. 7) and the region of precipitation between rain-bands 8 and 10 (shown in Fig. 4 as precipitation feature 9 and located between 70 and $98 \mathrm{~km}$ in section $\mathrm{C}$ of Fig. 7). In rainband 8 , at the level of the flight path, there were only rather small amounts of liquid water and their fluctuations were not very great. Whereas at flight level in precipitation feature 9 , the fluctuations in liquid water and vertical air velocities were much greater and similar to post-frontal activity. Observers on the aircraft reported that the area between rainbands 8 and 10 contained some cumulus clouds below the flight level $(775 \mathrm{mb})$. The precipitation intensity fell considerably between rainbands 8 and 10 .

\section{Internal structure and origin of the precipitation cores in the warm frontal rainbands}

The vertical structures of the precipitation cores in the warm frontal rainbands 3 and 4 were observed as they passed over the UW vertically pointing Doppler radar (Fig. 8). Between about 1334 and 1402 four distinct cores (labeled A, B, C and D in Fig. 8) passed over the radar. The tracks of two of these (C and D), determined from the UW surveillance radar, are shown in Fig. 9. The echoes which were traced were, for the most part, at the height of the melting layer.

The average fallspeeds of the precipitation particles, measured by the Doppler radar, and the horizontal winds, measured by the serial rawinsondes, were used to compute the trajectories of the precipitation particles comprising cores A-D (Fig. 8). The shape of the horizontal section through a precipitation core at the melting level (determined from the surveillance radar PPI displays), and the trajectories of the precipitation particles, were used to deduce the shape of a core (Fig. 10). The cores were then moved with appropriate velocities through the vertical beam of the Doppler radar, and the cuts which the vertical beam of the Doppler radar made through the cores were transcribed onto Fig. 8. The sections of cores $\mathrm{C}$ and $\mathrm{D}$ intersected by the vertically pointing Doppler radar beam are indicated by the hatched areas in Fig. 10. The precipitation from core $C$ reached the ground at the site of the UW Doppler radar, but the precipitation from core $D$ reached the ground to the north of the Doppler radar, even though most of the rest of this core passed over the Doppler radar. Apart from core D, the particles 
TABLE 3. Some characteristics of the precipitation cores within rainbands 3 and 4.

\begin{tabular}{|c|c|c|c|c|c|c|c|c|c|}
\hline \multirow[b]{2}{*}{$\begin{array}{c}\text { Core } \\
\text { number }\end{array}$} & \multicolumn{4}{|c|}{ Band 3} & \multicolumn{5}{|c|}{ Band 4} \\
\hline & $\begin{array}{l}\text { Average } \\
\text { area } \\
\left(\mathrm{km}^{2}\right)\end{array}$ & $\begin{array}{l}\text { Lifetime } \\
(\min )\end{array}$ & $\begin{array}{c}\text { Direction } \\
\text { of motion } \\
\text { (from true north) }\end{array}$ & $\begin{array}{c}\text { Speed } \\
\left(\mathrm{m} \mathrm{s}^{-1}\right)\end{array}$ & $\begin{array}{c}\text { Core } \\
\text { number }\end{array}$ & $\begin{array}{l}\text { Average } \\
\text { area } \\
\left(\mathrm{km}^{2}\right)\end{array}$ & $\begin{array}{l}\text { Lifetime } \\
\text { (min) }\end{array}$ & $\begin{array}{c}\text { Direction } \\
\text { of motion } \\
\text { (from true north) }\end{array}$ & $\begin{array}{r}\text { Speed } \\
\left(\mathrm{m} \mathrm{s}^{-1}\right)\end{array}$ \\
\hline 1 & 25 & $>30$ & $59^{\circ}$ & 25 & 1 & 50 & $>22$ & $55^{\circ}$ & 22 \\
\hline 2 & 50 & $>30$ & $62^{\circ}$ & 25 & $2^{*}$ & 25 & $>10$ & $20^{\circ}$ & 18 \\
\hline 3 & 50 & $>28$ & $68^{\circ}$ & 25 & 3 & 16 & $>4$ & & \\
\hline 4 & 200 & $>30$ & $55^{\circ}$ & 24 & 4 & 18 & $>10$ & $45^{\circ}$ & 24 \\
\hline 5 & 30 & $>2$ & & & 5 & 20 & $>15$ & $50^{\circ}$ & 23 \\
\hline 6 & 16 & 4 & & & 6 & 25 & $>20$ & $48^{\circ}$ & 25 \\
\hline 7 & 20 & 2 & & & 7 & 10 & $>2$ & & \\
\hline 8 & 30 & 10 & $49^{\circ}$ & 22 & $8 \mathrm{~A}$ & 20 & $>10$ & & \\
\hline 9 & 20 & 6 & & & $8 \mathrm{~B}$ & 20 & $>10$ & $50^{\circ}$ & 24 \\
\hline 10 & 16 & 2 & & & $9 \mathrm{~A}$ & 30 & $>32$ & $60^{\circ}$ & 21 \\
\hline 11 & 35 & 18 & $68^{\circ}$ & 25 & $9 \mathrm{~B}$ & 30 & $>32$ & $50^{\circ}$ & 22 \\
\hline 12 & 16 & 2 & & & 10 & 16 & 22 & $55^{\circ}$ & 24 \\
\hline 13 & 20 & 6 & & & 11 & 20 & 6 & & \\
\hline 14 & 16 & 2 & & & $12 \mathrm{~A}^{*}$ & 22 & $>18$ & $25^{\circ}$ & 27 \\
\hline $15^{*}$ & 20 & 16 & $22^{\circ}$ & 15 & $12 B$ & 22 & $>18$ & $30^{\circ}$ & 25 \\
\hline $16^{*}$ & 20 & 14 & $10^{\circ}$ & 20 & 13 & 16 & 8 & & \\
\hline 17 & 20 & 14 & $60^{\circ}$ & 27 & 14 & 20 & 16 & $55^{\circ}$ & 28 \\
\hline 18 & 16 & 2 & & & 15 & 20 & 4 & & \\
\hline 19 & 20 & 8 & $30^{\circ}$ & 17 & 16 & 20 & 4 & & \\
\hline $20^{*}$ & 35 & 12 & $35^{\circ}$ & 21 & 17 & 16 & 4 & & \\
\hline 21 & 20 & 10 & $60^{\circ}$ & 26 & 18 & 16 & 4 & & \\
\hline 22 & 16 & 8 & $50^{\circ}$ & 20 & 19 & 20 & $>10$ & $70^{\circ}$ & 27 \\
\hline 23 & 10 & 4 & & & 20 & 25 & $>8$ & $10^{\circ}$ & 22 \\
\hline 24 & 20 & 8 & & & 21 & 100 & $>4$ & & \\
\hline 25 & 20 & 8 & $32^{\circ}$ & 20 & 22 & 64 & $>2$ & & \\
\hline 26 & 30 & 6 & & & 23 & 10 & 6 & & \\
\hline 27 & 20 & 4 & & & 24 & 25 & $>6$ & $60^{\circ}$ & 25 \\
\hline 28 & 30 & 4 & & & 25 & 10 & 4 & & \\
\hline & & & & & 26 & 16 & 6 & & \\
\hline & & & & & 27 & 16 & 4 & & \\
\hline & & & & & 28 & 20 & $>5$ & & \\
\hline & & & $\cdot$ & & 29 & 20 & $>4$ & & \\
\hline & & & & & 30 & 22 & $>4$ & & \\
\hline & & & & & $31^{*}$ & 20 & $>13$ & $0^{\circ}$ & 13 \\
\hline & & & & & $32 *$ & 20 & $>13$ & $0^{\circ}$ & 13 \\
\hline & & & & & 33 & 100 & $>6$ & & \\
\hline
\end{tabular}

* Indicates that core was located in the southeastern portion of the band and tended to move more to the north.

associated with the other three cores produced increases in the precipitation rate at the UW (Fig. 8).

In Fig. 11 the average fallspeeds of the precipitation particles at different heights in cores $\mathrm{A}, \mathrm{B}, \mathrm{C}$ and $\mathrm{D}$ are related to the height intervals over which various ice crystals would grow under water-saturated conditions (Magono and Lee, 1966). Also shown in Fig. 11 is the envelope of the particle trajectories in core $\mathrm{C}$ and the $0 \mathrm{~m} \mathrm{~s}^{-1}$ Doppler fallspeed. These data reveal the following:

- The precipitation cores originated in generating cells which were located in the upper regions of the cores. The location of the potentially unstable layer shown in Fig. 8 suggests that the generating cells were produced when portions of this layer were lifted sufficiently to release the potential instability, thereby producing shallow convective cells. This interpretation is supported by the fact that the layer in the atmosphere over which the wind speeds and directions corresponded to the motions of the cores is the same as the layer of potentially unstable air (Fig. 11). Similar comparisons for the other rainbands (including the cold frontal bands) shown in Fig. 4 indicate that cores in these rainbands also moved with the direction and speed of the air within shallow, potentially unstable, layers.

- The initial rapid growth (as indicated by the vertical gradient of average fallspeed) of the precipitation particles in the generating cells occurred in the dendritic growth region. In the lower portion of the generating cells the average velocity $\left(0.7 \mathrm{~m} \mathrm{~s}^{-1}\right)$ is higher than that of single dendrites but it is appropriate for aggregates of dendrites $1 \mathrm{~mm}$ in diameter and 0.03 mg in mass (Locatelli and Hobbs, 1974). Also, the rate at which the fallspeed increased with the fall distance $\left(1.2 \mathrm{~m} \mathrm{~s}^{-1}\right.$ per $\left.\mathrm{km}\right)$ is too high for depositional growth alone but it is consistent with growth by aggregation or riming (Weiss and Hobbs, 1975). 

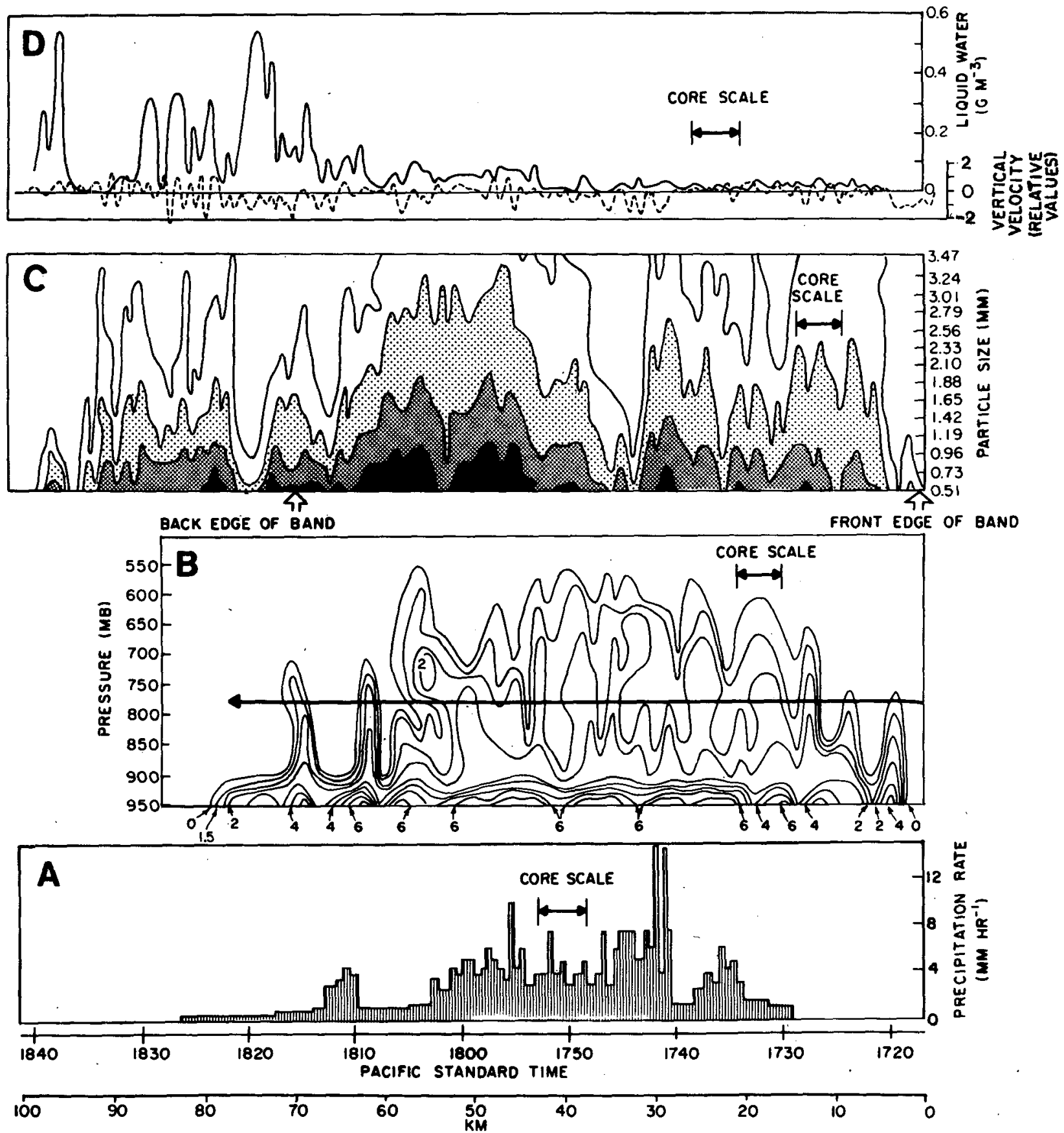

FIG. 7. Airborne, radar and raingage data taken in rainband 8. Precipitation rates at UW are shown in $A$. The time-height section of the average fallspeeds of precipitation particles, as measured by the Doppler radar, is shown in B. Velocity contours are labeled in $\mathrm{m} \mathrm{s}^{-1}$. The heavy arrow shows the height at which the aircraft passed through the band. Particle spectra measurements are shown in $\mathrm{C}$. Concentrations of particles per $100 l$ of air are indicated by nonhatched area $(2-10)$; lightly dotted area (10-50); heavily dotted area (50-200); and black areas (200-500). Cloud liquid water content (solid line) and vertical air velocity (dashed line) as measured by the aircraft are shown in $\mathrm{D}$. The time scale applies only to the precipitation data, while the approximate distance scale applies to all four sections.

- Below the dendritic growth region the rate of increase in fallspeed with decreasing height decreased, but it was still greater than that expected from depositional growth alone. We conclude therefore that as aggregated dendrites from the generating cells fell through the plate and columnar growth region, they continued to grow by aggregation and riming. Aggregates of this type would have had to attain a mass of $0.06 \mathrm{mg}$ and dimensions of $1.3 \mathrm{~mm}$ in order to fall at the measured speeds (Fig. 11). 


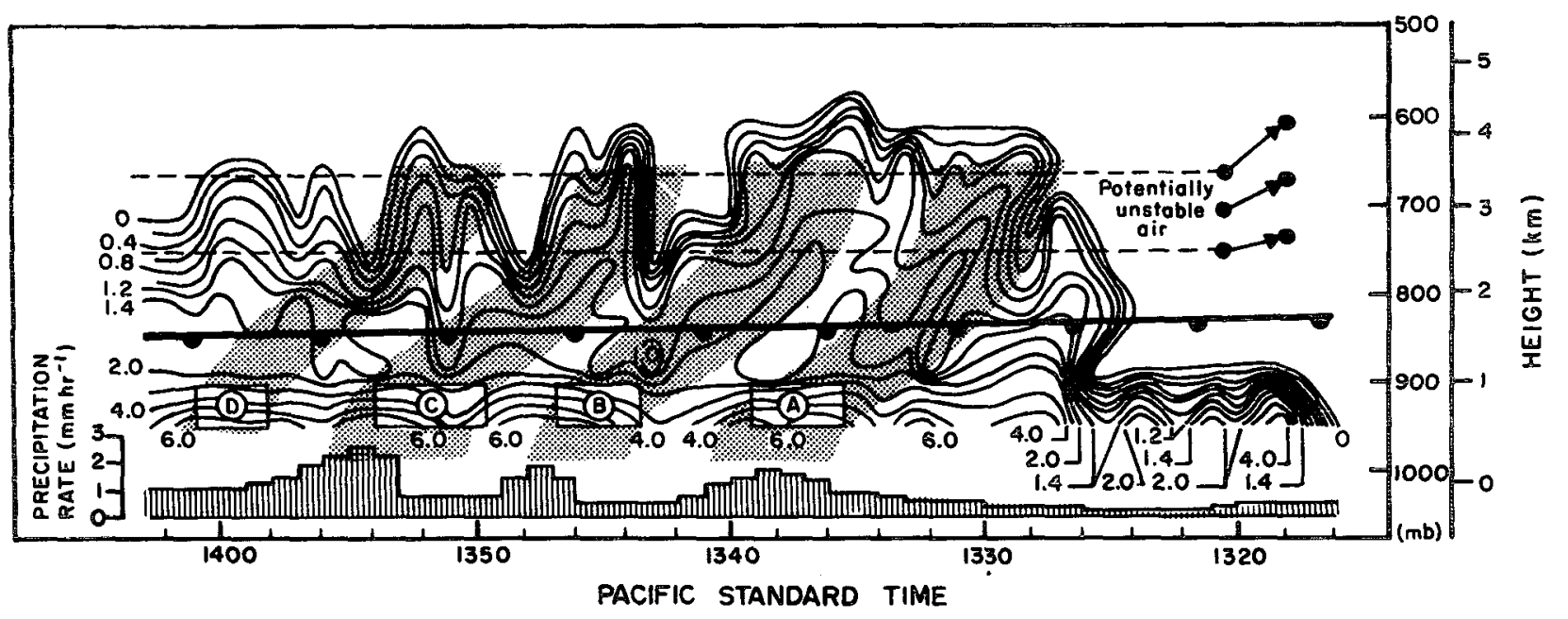

FIG. 8. Time-height section of the radar power-weighted average fallspeeds of precipitation particles as measured by the UW verticallypointing Doppler radar. Velocity contours are labeled in units of $\mathrm{m} \mathrm{s}^{-1}$. The precipitation rates are 1 min averages measured on the ground at the UW. The rectangles show the interpolated times that cores A, B, C, D (as determined by the UW surveillance radar) passed over the Doppler radar. The trajectories of precipitation particles for cores A, B, C and D are shown by the hatching. The black circles and arrows indicate the heights to which the potentially unstable layer (located between the dashed lines) would have to be lifted to become absolutely unstable.

- Further growth of the dendrites by aggregation occurred in the needle and sheath region. In falling through this region, the "average" particle increased in mass by about a factor of 10 and in size by $5 \mathrm{~mm}$.

- In the plate region further growth occurred, doubling the mass of the "average" particle.

- Sharp increases occurred in the average fallspeed as the dendritic aggregates passed through the melting layer, and they reached the ground as rain.

The above observations indicate that the generating cells provided seed ice crystals, in the form of aggregated dendrites, which fell into lower cloud layers where they continued to grow by aggregation and riming as they swept up the condensation products (ice and water) produced by larger mesoscale motions or synoptic scale lifting of the air. (These same large scale motions could have been responsible for the lifting of the potentially unstable layers of air which produced the generating cells.) The streamers from the generating cells increased precipitation sufficiently over small mesoscale areas to become manifested as precipitation cores within the rainbands.

\section{Summary and conclusions}

In this study we have used satellite, radar, airborne and ground observations to investigate the mesoscale organization of precipitation in one cyclonic storm system. The precipitation was contained in large mesoscale regions, most of which were in the form of rainbands; some characteristics of several of these rainbands have been described. The rainbands contained smaller mesoscale regions of precipitation
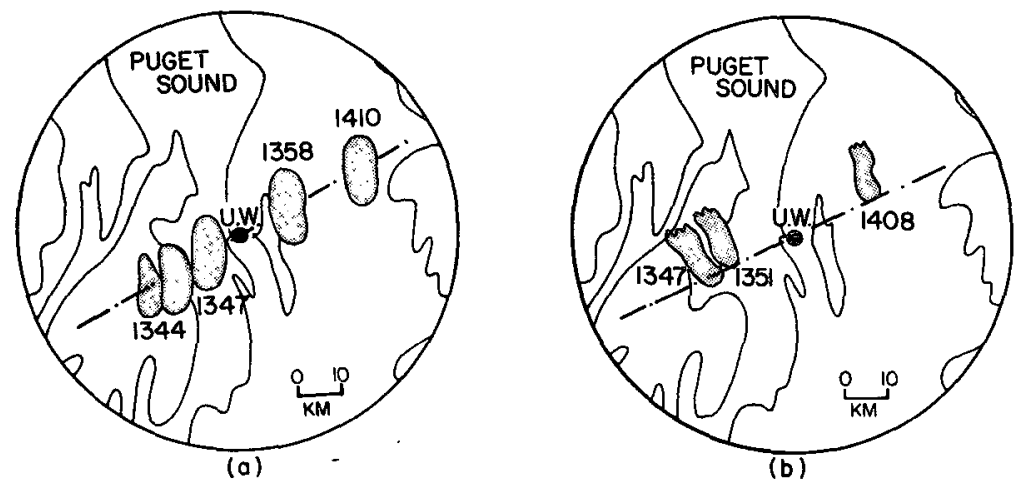

FIG. 9. The positions of (a) core $\mathrm{C}$ and (b) core $\mathrm{D}$ (hatched areas) as determined by PPI radar displays. The number alongside each position is the Pacific Standard Time. UW marks the position of the University of Washington. 

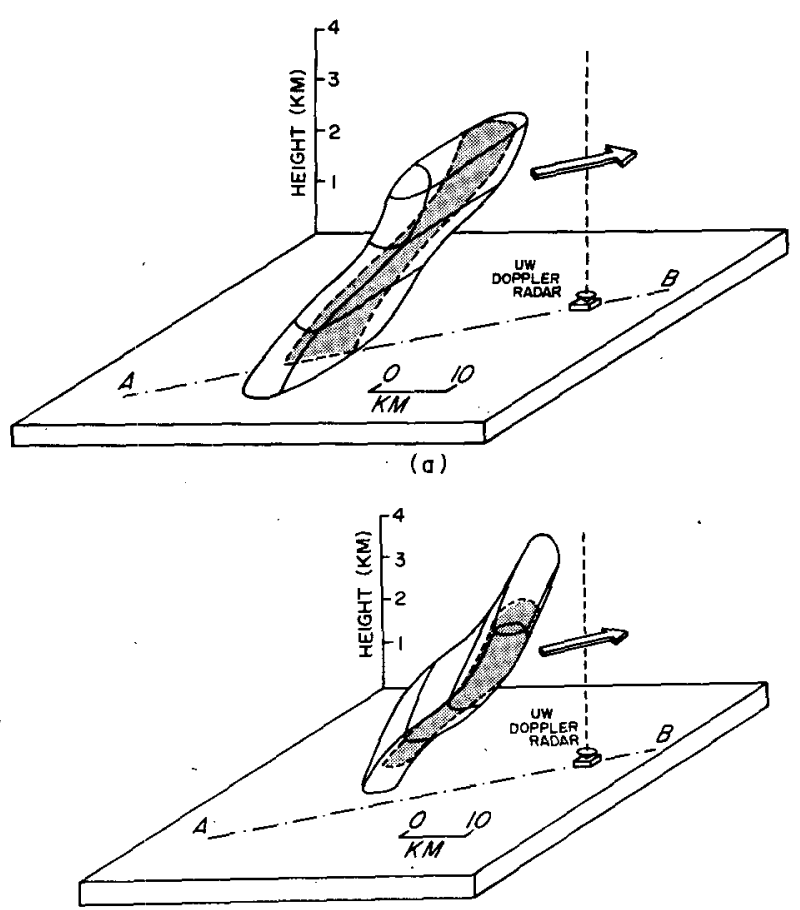

(b)

FIG. 10. The three-dimensional shapes of (a) core $C$ and (b) core $\mathrm{D}$. The cores moved along $\mathrm{AB}$ in the direction shown by the arrows. The shaded regions inside the cores are the cross sections which the vertically pointing Doppler radar beam cut through the cores.

(called precipitation cores in this paper) which could be discerned in the radar, airborne and ground measurements.
The internal structures of a number of the precipitation cores were investigated by simultaneous Dopper radar and airborne measurements. It was found that the precipitation cores in the warm frontal bands originated in higher level cloud layers (called generating cells by previous workers) which produced streams of ice crystals which grew by collection as they fell through lower cloud layers. There is strong evidence that the generating cells were produced by the lifting of shallow layers of potentially unstable air which were situated above the warm fronts. These observations clearly demonstrate the connection between generating cells and the organization of precipitation on the mesoscale in the warm frontal region of the cyclonic storm which we have described.

Most of the information on generating cells presented in this paper (and also by previous workers) has been confined to warm frontal precipitation. However, we have shown that the precipitation cores within both the warm frontal and the cold frontal bands had similar sizes and were similarly distributed. Moreover, in both the warm and cold frontal bands the cores moved with the speed and in the direction of the wind at higher levels where the air was potentially unstable. It is possible therefore that generating cells play similar roles in cold and warm frontal rainbands.

In this paper we have been concerned with the role of generating cells in rainbands; in a future paper (Herzegh and Hobbs, 1978) we will discuss the role of generating cells in the more stratiform precipitation associated with prefrontal conditions in cyclonic storms.

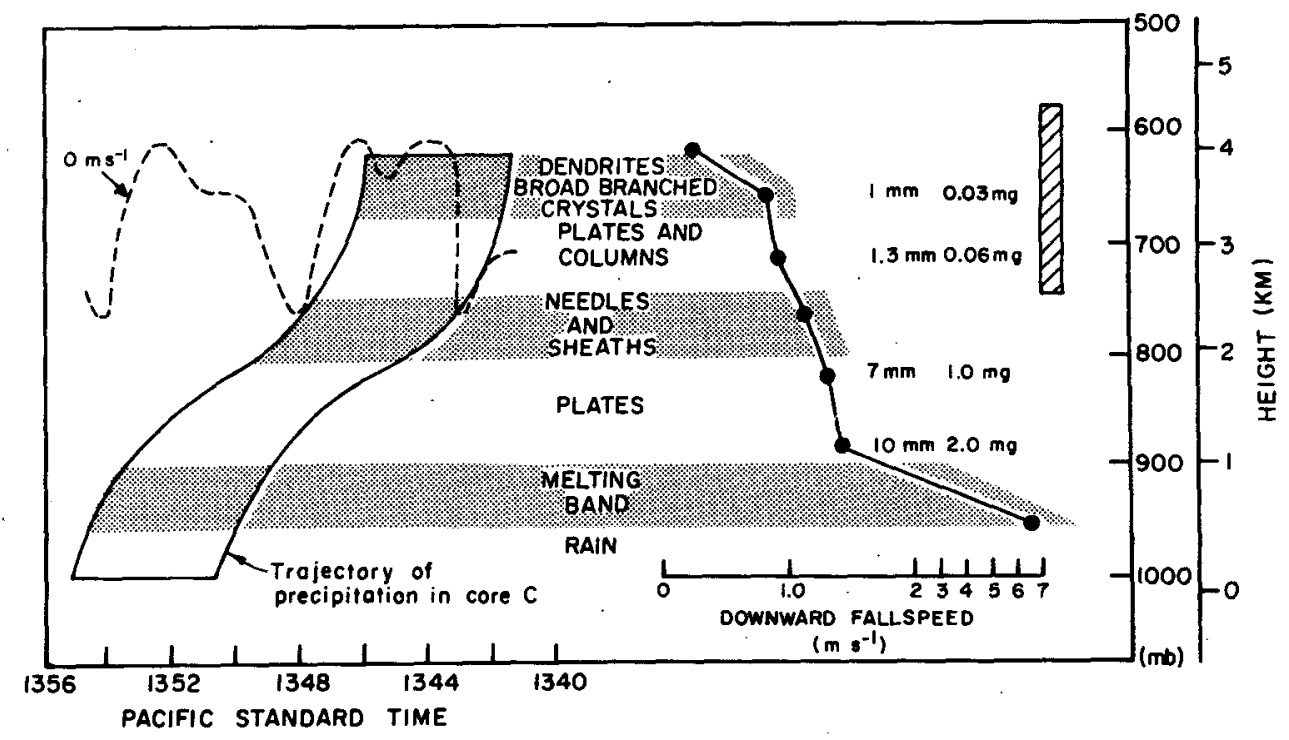

FIG. 11. The radar measured average fallspeeds of the precipitation particle as a function of height for precipitation cores A, B, C and D (black dots). Shown on the left-hand side is the $0 \mathrm{~m} \mathrm{~s}^{-1}$ contour (dashed line) and the envelope of the particle trajectories in core $C$. Also shown are the growth regions for various crystals, the masses and sizes of the precipitation particles (assumed to be dendritic aggregates) corresponding to the average fallspeeds, and the height intervals (hatched area) over which the wind speed and direction corresponded to the motion of the cores. 
Acknowledgments. We wish to thank all our colleagues who participated in this work, particularly Dr. R. R. Weiss, Sr., for operating the UW radar, and Prof. R. A. Houze, Jr., for his helpful comments during the preparation of this paper. We also thank the personnel from the National Center for Atmospheric Research (which is sponsored by the National Science Foundation) who operated the $\mathrm{C}$-band radar and the Sabreliner aircraft.

This research was supported by the Atmospheric Research Section (Meteorology Program) of the National Science Foundation under Grant ATM-7414726-A02.

\section{REFERENCES}

Austin, P. M., and R. A. Houze, Jr., 1972: Analysis of the structure of precipitation patterns in New England. J. Appl. Meteor., 11, 926-935.

Boucher, R. J., 1959: Synoptic-physical implication of $1.25 \mathrm{~cm}$ vertical-beam radar echoes. J. Meteor., 16, 312-326.

Bowen, E. G., 1951 : Radar observations on rain and their relation to mechanisms of rain formation. J. Atmos. Terr. Phys., 1, 125-129.

Browne, I. C., 1952 : Precipitation streaks as a cause of radar upper bands. Quart. J. Roy. Meteor. Soc., 78, 590-595.

Browning, K. A., M. E. Hardman, T. W. Harrold and C. W.
Pardoe, 1973: The structure of rainbands within a midlatitude depression. Quart. J. Roy. Meteor. Soc., 99, 215-231.

Gray, G. R., R. J. Serafin, D. Atlas, R. E. Rinehart and J. J. Boyajian, 1975: Real-time color Doppler radar display. Bull. Amer. Meteor. Soc, 56, 580-588.

Herzegh, P. H., and P. V. Hobbs, 1978: Manuscript in preparation.

Hobbs, P. V., R. A. Houze, Jr. and T. J. Matejka, 1975: The dynamical and microphysical structure of an occluded frontal system and its modification by orography. J. Atmos. Sci., 32, 1542-1562.

Houze, R. A., Jr., P. V. Hobbs, K. R. Biswas and W. M. Davis, 1976: Mesoscale rainbands in extratropical cyclones. Mon. Wea. Rev., 104, 868-878.

Locatelli, J. D., and P. V. Hobbs, 1974: Fallspeeds and masses of solid precipitation particles. J. Geophys. Res., 79, 21852197.

Magono, C., and C. V. Lee, 1966: Meteorological classification of natural snow crystals. J. Fac. Sci. Hokkaido Univ., Ser. 7, $2,321-362$.

Marshall, J. S., 1953: Precipitation trajectories and patterns. J. Meteor., 10, 25-29.

Plank, V. G., D. Atlas and W. H. Paulsen, 1955: The nature and detectability of clouds and precipitation as determined by 1.25 centimenter radar. $J$. Meteor., 12, 358-377.

Weiss, R. R., and P. V. Hobbs, 1975: The use of a vertically pointing pulsed Doppler radar in cloud physics and weather modification studies. J. Appl. Meteor., 14, 222-231.

Wexler, R., and D. Atlas, 1959: Precipitation generating cells. J. Meteor., 16, 327-332. 